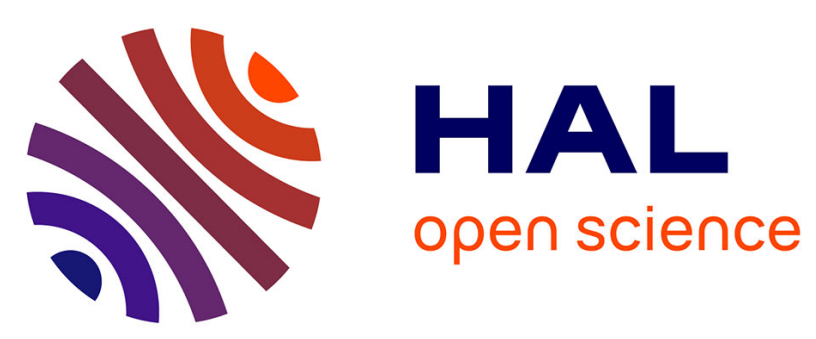

\title{
The Combination of 4-Hydroxythiazoles with Azaheterocycles: Efficient bidentate Ligands for novel Ruthenium Complexes
}

\author{
Rainer Beckert, Dieter Weiss
}

\section{- To cite this version:}

Rainer Beckert, Dieter Weiss. The Combination of 4-Hydroxythiazoles with Azaheterocycles: Efficient bidentate Ligands for novel Ruthenium Complexes. Journal of Inorganic and General Chemistry / Zeitschrift für anorganische und allgemeine Chemie, 2010, 636 (7), pp.1380. 10.1002/zaac.200900523 . hal-00552434

\author{
HAL Id: hal-00552434 \\ https://hal.science/hal-00552434
}

Submitted on 6 Jan 2011

HAL is a multi-disciplinary open access archive for the deposit and dissemination of scientific research documents, whether they are published or not. The documents may come from teaching and research institutions in France or abroad, or from public or private research centers.
L'archive ouverte pluridisciplinaire HAL, est destinée au dépôt et à la diffusion de documents scientifiques de niveau recherche, publiés ou non, émanant des établissements d'enseignement et de recherche français ou étrangers, des laboratoires publics ou privés. 


\section{Zeitschrift für Anorganische und}

Allgemeine Chemie

The Combination of 4-Hydroxythiazoles with Azaheterocycles: Efficient bidentate Ligands for novel Ruthenium Complexes

\begin{tabular}{|r|l|}
\hline Journal: & Zeitschrift für Anorganische und Allgemeine Chemie \\
\hline Manuscript ID: & zaac.200900523 \\
\hline Wiley - Manuscript type: & Article \\
\hline Author: & 17-Nov-2009 \\
\hline Komplete List of Authors: & $\begin{array}{l}\text { Beckert, Rainer; Institut für Organische und Makromolekulare } \\
\text { Chemie, Chemisch-Geowiss. Fakultät } \\
\text { Weiss, Dieter; Institut für Organische und Makromol. Chemie, } \\
\text { Chem.-Geowiss. Fakultät }\end{array}$ \\
\hline \multicolumn{2}{|l}{ Khiazoles, Ruthenium Complexes, Fluorescence, Emission, Lifetime } \\
\hline $\begin{array}{l}\text { Note: The following files were submitted by the author for peer review, but cannot be converted } \\
\text { to PDF. You must view these files (e.g. movies) online. }\end{array}$ \\
\hline $\begin{array}{l}\text { Scheme1.cdx } \\
\text { Figure1.cdx } \\
\text { Figure 4.hgl }\end{array}$ \\
\hline
\end{tabular}




\title{
Articel
}

DOI: 10.1002/zaac.200((will be filled in by the editorial staff))

\section{The Combination of 4-Hydroxythiazoles with Azaheterocycles: Efficient bidentate Ligands for novel Ruthenium Complexes}

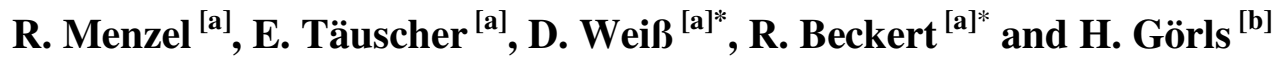 \\ Dedicated to ... on the Occasion of ... ((optional))
}

Keywords: Thiazoles; Fluorescence; Ruthenium Complexes; Emission, Lifetime

We report here on the synthesis of three novel ligands in which an azaheterocycle is connected with a thiazole subunit: 4-methoxy-5methyl-2-pyridine-2-yl-1,3-thiazole (1), 4-methoxy-5-methyl-2pyrimidine-2-yl-1,3-thiazole (2) and 4-methoxy-5-phenyl-2pyridine-2-yl-1,3-thiazole (3). Being cyclic versions of 1,4diazadienes, they offer good prerequisites for the synthesis of metal complexes and have been employed as chelating ligands. Three novel heteroleptic cationic complexes of the type
$\operatorname{Ru}(\text { bpy })_{2}(\mathbf{L})$, with bpy $=2,2^{\prime}$-bipyridine have been successfully synthesized. The $\mathrm{Ru}(\mathrm{II})$ complexes as well as the ligands were characterized by means of mass spectrometry, NMR, UV/Vis and IR spectroscopy and elemental analysis. Furthermore, an X-ray structure of $\mathrm{Ru}(\mathrm{bpy})_{2} \mathbf{2}\left(\mathrm{PF}_{6}\right)$, as far as we know the first example where a thiazole is directly connected to a $\mathrm{Ru}(\mathrm{II})$ core, is presented in this paper.

\section{Introduction}

Ruthenium compounds, in particular Ru(II) polypyridine complexes, are one class of transition metal complexes showing outstanding photochemical properties and the development of novel Ru(II) complexes has undergone an impressive growth, especially in the last 15 years. Exhaustive reviews concerning $\mathrm{Ru}(\mathrm{II})$ polypyridine complexes have been published [1]. They play a central role in artificial photosynthesis, in particular, in the design of dye-sensitized solar cells (DSC's) [2]. Furthermore, they are used in supramolecular chemistry, organic light emitting diodes (OLED's), electroluminescent devices and as catalysts. A new increasingly important research field where $\mathrm{Ru}$ complexes are utilized is in the photoelectrochemical reduction of $\mathrm{CO}_{2}$ to form a useful fuel [3]. A recently published paper, for example, describes an unexpected high activity of similar benzothiazole and bithiazole $\mathrm{Ru}(\mathrm{II})$ complexes for $\mathrm{CO}_{2}$ reduction [4].

Because of their various capabilities, there still exists an immense interest in new $\mathrm{Ru}(\mathrm{II})$ complexes with distinct properties. The class of $\mathrm{Ru}(\mathrm{II})$ complexes containing a thiazole based ligand is absolute underrepresented and only a few examples are known [5].

[a] Institute of Organic and Macromolecular Chemistry Friedrich Schiller Universität Jena

Humboldtstraße 10

D-07743 Jena, Germany

* PD Dr. D. Weiß, Prof. Dr. R. Beckert Fax: +49-3641-948212

E-mail: Dieter.Weiss@uni-jena.de; c6bera@uni-jena.de

[b] Institute of Inorganic and Analytical Chemistry,

Friedrich Schiller Universität Jena
Thiazoles connected to an aromatic heterocycle show interesting photophysical properties [6] and might act as light harvesting or bridging ligands in several transition metal complexes. In addition, due to the strong fluorescence of the thiazole ligands connected with the versatile hydroxy group, they might be employed as easily binding sensor molecules [7].

\section{Results and Discussion}

The 4-hydroxythiazoles which lead to ligand $\mathbf{1}$ and $\mathbf{2}$ have been prepared following a protocol established by our group [8]. The 4-hydroxythiazole of ligand $\mathbf{3}$ was synthesized using a slightly modified method. At first, a nitrile, here pyridine-2-carbonitrile, reacts with hydrogen sulfide forming the corresponding thioamide which was then cyclized with ethyl 2-bromophenylacetate to yield the 4hydroxythiazole. Methyl iodide was chosen as the electrophile for a Williamson type etherification of the 4hydroxythiazoles. Both methods and the structures of the ligands are depicted in Scheme 1

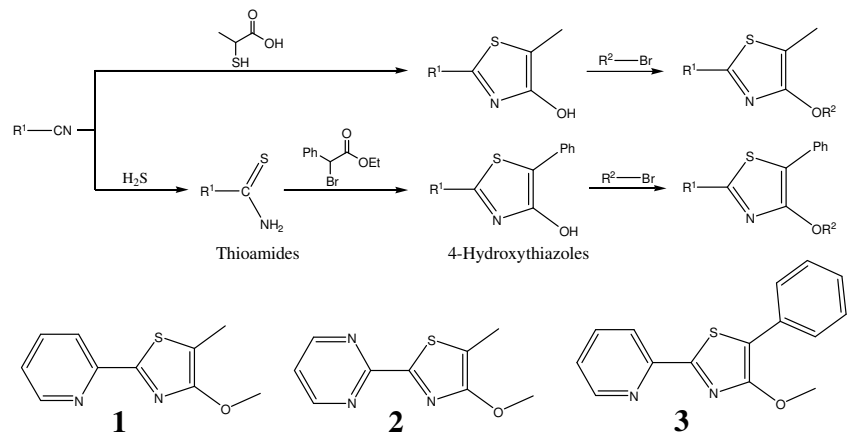

Scheme 1. General synthetic routes and structures of the three thiazole ligands obtained. 
The complexes were synthesized using the precursor cis-(bpy) $)_{2} \mathrm{RuCl}_{2}$, which was prepared by following a literature procedure [9]. The structures of the synthesized complexes are shown in Figure 1.
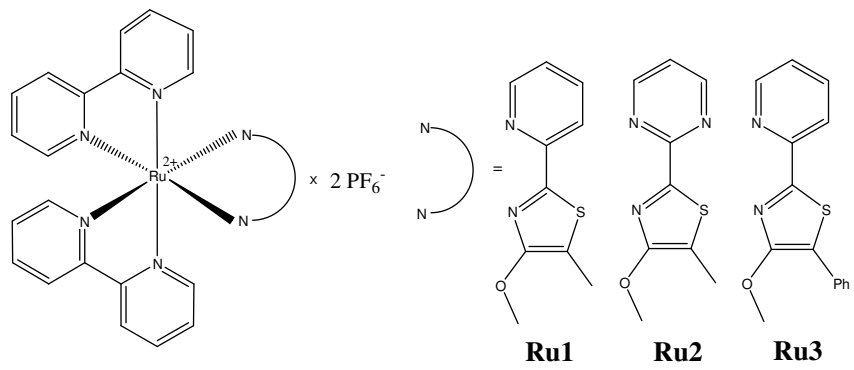

Figure 1. Structures of the $\mathrm{Ru}(\mathrm{bpy})_{2}(\mathbf{L})\left(\mathrm{PF}_{6}\right)_{2}$ complexes.

A standard synthesis with the precursor was not successful. The cis-(bpy) ${ }_{2} \mathrm{RuCl}_{2}$ must be transformed to the activated

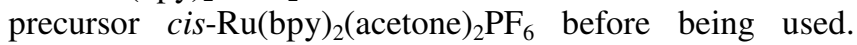
Therefore, cis-(bpy $)_{2} \mathrm{RuCl}_{2}$ was stirred with $\mathrm{AgPF}_{6}$ in dry and degassed acetone under an inert atmosphere [10]. The complexes were finally obtained by heating the activated precursor with an equimolar amount of ligand in acetone. Gel filtration was used to remove traces of ligand and silver impurities. The yield was moderate to good $(53-68 \%)$.

\section{Electronic Properties}

The ligands show various absorption bands in the UV/Visspectra with a molar extinction coefficient of over $70000 \mathrm{M}^{-1} \mathrm{~cm}^{-1}$ and hence are $\pi \rightarrow \pi^{*}$ and not $\mathrm{n} \rightarrow \pi^{*}$ transitions. The absorption and emission spectra of the ligands are depicted in Figure 2. The shortest wave-length absorptions, at about $240 \mathrm{~nm}$, correspond to the $\pi \rightarrow \pi^{*}$ transition based on the azaheterocyclic moiety. The second, thiazole based $\pi \rightarrow \pi^{*}$ transition is at $350 \mathrm{~nm}$ and is red-shifted $(25 \mathrm{~nm})$ for 3 to $375 \mathrm{~nm}$, due to the additional aromatic phenyl ring lowering the energy gap between ground $\left(\mathrm{S}_{0}\right)$ and exited state $\left(\mathrm{S}_{1}\right)$. Additionally, a third absorption band at $273 \mathrm{~nm}$ can be observed for $\mathbf{3}$ which belongs to the $\pi \rightarrow \pi^{*}$ transition ( $K$-band) based on the phenyl ring [11]. The thiazoles show strong blue room temperature fluorescence in solution $\left(\mathrm{CH}_{2} \mathrm{Cl}_{2}\right)$. The $\lambda_{\max }$ of the emission is at $420 \mathrm{~nm}$ for $\mathbf{1}$ and $\mathbf{2}$. For $\mathbf{3}$ the $\lambda_{\max }$ is red shifted $(29 \mathrm{~nm})$ to $448 \mathrm{~nm}$, which is in accordance with the absorption spectra. Additionally, this indicates that the fluorescence arises basically from the $S_{1}$ state located at the thiazole moiety. The Stokes shift is comparatively large for these small molecules and can be assigned to a significant geometry change in the $S_{1}$ state [6]. The fluorescence quantum yields are high and almost unity for 3 . The fluorescence lifetimes are in the normal range and vary from 2 - 4 ns [6].

The absorption and emission spectra of the complexes, together $\mathrm{Ru}(\mathrm{bpy}){ }_{3}{ }^{2+}$ as a reference, are shown in Figure 3. All complexes show strong ligand centered (LC) absorptions of the bpy ligands at around $285 \mathrm{~nm}$. The LC transitions of the coordinated thiazole ligands are also present in the complexes and are located at $352 \mathrm{~nm}, 332 \mathrm{~nm}$ and $368 \mathrm{~nm}$ for Ru1, Ru2 and Ru3, respectively. The shoulders at $322 \mathrm{~nm}$ in Ru1 and Ru3 can be assigned to metal center MC transitions which are superimposed in Ru2 with the intense thiazole-based LC transition. The bands at 240 and $450 \mathrm{~nm}$ are metal to ligand (MLCT) transitions. The $\lambda_{\max }$ of the longest wave-length absorption is slightly red-shifted $(4 \mathrm{~nm})$ for Ru1 and Ru3 compared to $\mathrm{Ru}(\mathrm{bpy})_{3}{ }^{2+}$. Due to the especially broad nature of the MLCT of Ru2, an exact assignment of the longest wave-length absorption is not possible (a shoulder is present at around $465 \mathrm{~nm}$ ). The $\lambda_{\max }$ of the emission varies from 637 to $665 \mathrm{~nm}$ and is correlated to the electronic properties of the thiazole ligands. A strong $\pi$-acceptor such as pyrimidine lowers the $\pi^{*}{ }_{L}$ (LUMO) of the complex and therefore decreases the energy of the MLCT state. This leads to a bathochromic shift of the $\lambda_{\max }$ of the absorption $\left({ }^{1}\right.$ MLCT) and also the emission band $\left({ }^{3}\right.$ MLCT) of the MLCT transitions. This can be observed for Ru2 compared to Ru1. The higher $\pi$-acceptor strength of the pyrimidine heterocycle is also expressed in a higher oxidation potential of $0.85 \mathrm{~V}$ for $\mathbf{R u} \mathbf{1}$ compared to $0.81 \mathrm{~V}$ for Ru2. Additionally, a more extended $\pi$ system, like in ligand 3 , lowers the energy of the $\pi_{L}^{*}$ orbital ( $\pi^{*}$-tuning). Therefore, the $\lambda_{\max }$ of the emission of $\mathbf{R u 3}$ is also red-shifted compared to Ru1. A second effect is a higher energy gap between the ${ }^{3} \mathrm{MLCT}$ and the non-radiative ${ }^{3} \mathrm{MC}$ state leading to a less probable population of the latter and, consequently, to an extended lifetime of the emitting state. This is in accordance with the measured values of $\mathbf{R u} 3$ compared to Ru1. The emission quantum yields obtained at room temperature are good and in the range of $2 \%$ despite the use of aerated $\mathrm{CH}_{2} \mathrm{Cl}_{2}$ in which oxygen acts as a quencher. All values are summarized in Table 1 .

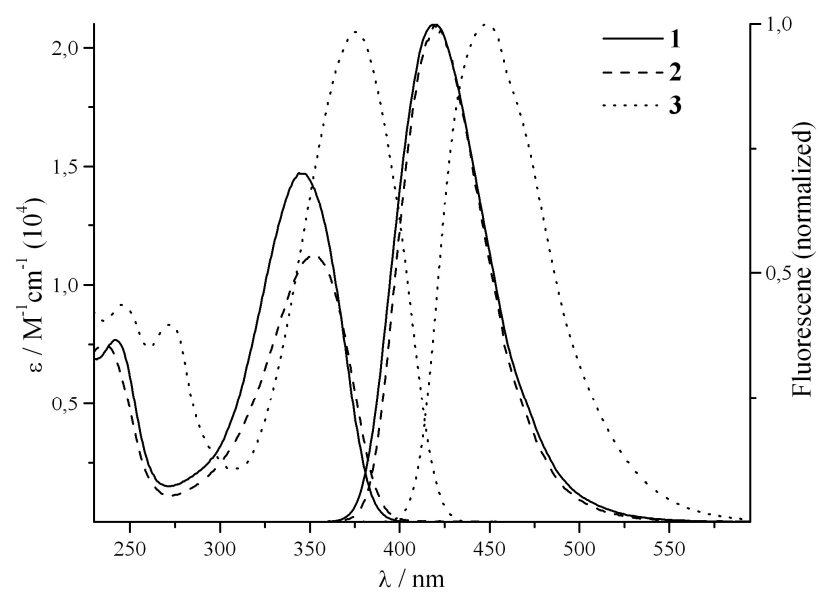

Figure 2. UV/Vis and fluorescence spectra of the ligands $\mathbf{1}$ to $\mathbf{3}$ measured in $\mathrm{CH}_{2} \mathrm{Cl}_{2}$ at room temperature.

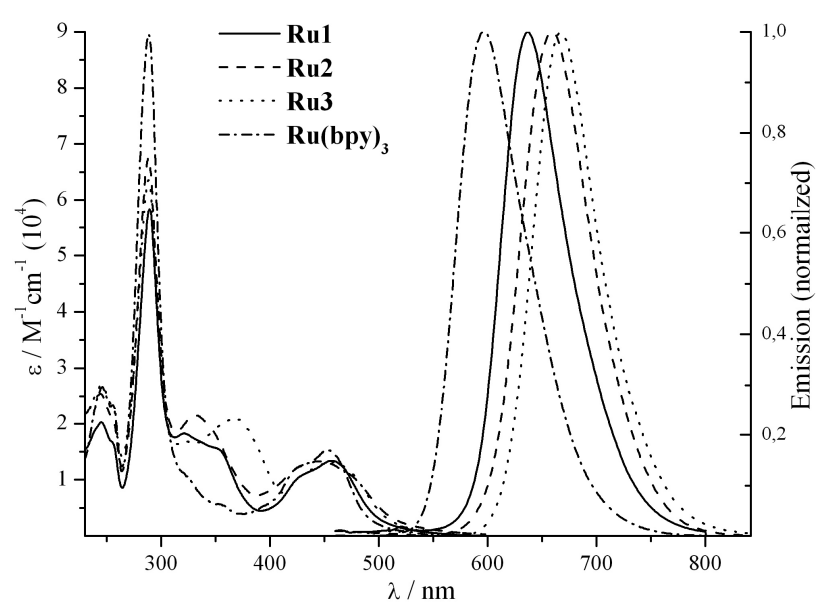

Figure 3. UV/Vis and emission spectra of Ru1 to Ru3 and

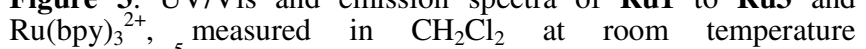
$\left(c \approx 1.5 \times 10^{-5} \mathrm{~mol} / \mathrm{L}\right)$. 
Table 1. Spectroscopic data of ligands $\mathbf{1 - 3}$ and the complexes Ru1 - Ru3 and Ru(bpy) ${ }_{3}{ }^{2+}$. All measurements were made in aerated $\mathrm{CH}_{2} \mathrm{Cl}_{2}$ at $298 \mathrm{~K}$

\begin{tabular}{|c|c|c|c|c|c|}
\hline Ligands & $\lambda_{\mathrm{Abs}} / \mathrm{nm}[\log \varepsilon]$ & $\lambda_{\mathrm{Fl}} / \mathrm{nm}^{[\mathrm{a}]}$ & Stokes-Shift $/ \mathrm{cm}^{-1[\mathrm{~b}]}$ & $\tau / \mathrm{ns}^{[\mathrm{d}]}$ & $\Phi$ in $\%$ \\
\hline 1 & 241 [3.89], 344 [4.17] & 419 & 5203 & 3.6 & 90 \\
\hline 2 & $236[3.87], 352[4.05]$ & 421 & 4656 & 2.8 & 60 \\
\hline 3 & $246[3.96], 273[3.92], 376[4.32]$ & 448 & 4345 & 3.9 & 100 \\
\hline Complexes & $\lambda_{\mathrm{Abs}} / \mathrm{nm}[\log \varepsilon]$ & $\lambda_{\mathrm{Em} .} / \mathrm{nm}^{[\mathrm{c}]}$ & & $\tau / \mathrm{ns}^{[\mathrm{d}]}$ & $\Phi$ in $\%$ \\
\hline $\mathbf{R u}(\mathbf{b p y})_{3}$ & $246[4.43], 289[4.95], 322[4.04], 453$ [4.19] & 608 & & $885^{[\mathrm{e}]}$ & $6.2^{[\mathrm{e}]}$ \\
\hline Ru1 & $244[4.31], 288[4.80], 321[4.26], 457[4.12]$ & 637 & & 378 & 2.0 \\
\hline Ru2 & $245[4.40], 289[4.83], 332[4.33], 446[4.12]$ & 659 & & 253 & 1.9 \\
\hline Ru3 & $246[4.43], 289[4.83], 368[4.32], 457[4.12]$ & 667 & & 412 & 2.0 \\
\hline
\end{tabular}

[a] excitation in the absorption maximum, [b] related to the maximum of the longest wave-length absorption, [c] excitation at $\lambda=450 \mathrm{~nm}$, [d] excitation at $\lambda=435 \mathrm{~nm}$, [e] value obtained from Ref. [12].

\section{Crystal structure of $R u(b p y)_{2} 2\left(P F_{6}\right)_{2}$}

Single crystals suitable for X-ray structure analysis were obtained by slow ether diffusion in an acetonitrile solution of the corresponding complex Ru2. An ORTEP draw of the complex is shown in Figure 4. The complex Ru2 crystallizes as red needles in the monoclinic space group $P 2{ }_{1} /$ c. The methoxy group of the complex is slightly displaced, which does not effect the relevant information. The typical distorted octahedral coordination geometry of the complex forces the aromatic rings of the thiazole ligand into an almost coplanar orientation (torsion angles N1-C4C5-N3 $0.24^{\circ}$, N2-C4-C5-S1 $1.29^{\circ}$ ). The Ru-N bond lengths and $\mathrm{N}-\mathrm{Ru}-\mathrm{N}$ bond angles for the bpy ligands are in the normal range (e.g. Ru1-N4 2.059(5) A, Ru1-N5 2.047(5) Å) as reported for this type of $\mathrm{Ru}(\mathrm{II})$ complexes [13]. The Ru-N bond lengths from the thiazole ligand to the metal centre are

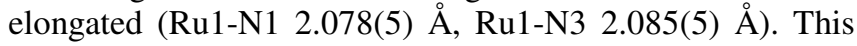
can be ascribed to a less $\pi *$ backbonding from the thiazole to the $\mathrm{Ru}(\mathrm{II})$, which has been observed for similar complexes like $\left[\mathrm{Ru}(\mathrm{bpy})_{2}(\mathrm{cept})\right]^{+} \quad(\mathrm{cept}=3-$ (ethoxycarbonyl)-5-(pyrid-2'-yl)-1,2,4-triazolate) [14] and $\left[\mathrm{Ru}(\mathrm{bpy})_{2} \mathrm{TPZ}\right]^{2+}(\mathrm{TPZ}=2-(1, H$-tetrazol-5-yl)pyrazine $)[15]$. The bond angle N1-Ru1-N3 of the bidentate thiazole to the $\mathrm{Ru}(\mathrm{II})$ core is slightly diminished $\left(78.4(2)^{\circ}\right)$ compared to the bond angle formed from the bpy ligands (e.g. N5-Ru1-N4 $\left.79.23(19)^{\circ}\right)$. This can be explained with the elongated $\mathrm{N} 1 / \mathrm{N} 3-\mathrm{Ru} 1$ bonds, leading to a diminished N1-Ru1-N3 bond angle. This effect also compensates for the influence of the smaller bond angle N3-C5-S1 $\left(114.7(6)^{\circ}\right)$ of the fivemembered thiazole-ring, which normally should lead to an expand N1-Ru1-N3 bond angle.

Table 2. Selected bond lengths / A and angles / ${ }^{\circ}$ of Ru2.

\begin{tabular}{llll}
\hline Bond lengths & & Bond angles \\
$\mathrm{Ru} 1-\mathrm{N} 1$ & $2.078(5)$ & $\mathrm{N} 1-\mathrm{Ru} 1-\mathrm{N} 3$ & $78.4(2)$ \\
$\mathrm{Ru} 1-\mathrm{N} 3$ & $2.085(5)$ & N1-Ru1-N4 & $88.12(88)$ \\
$\mathrm{Ru} 1-\mathrm{N} 4$ & $2.059(5)$ & N1-Ru1-N5 & $93.94(19)$ \\
$\mathrm{Ru} 1-\mathrm{N} 5$ & $2.047(5)$ & N1-Ru1-N7 & $96.46(18)$ \\
$\mathrm{Ru} 1-\mathrm{N} 6$ & $2.050(5)$ & N3-Ru1-N4 & $95.75(19)$ \\
$\mathrm{Ru} 1-\mathrm{N} 7$ & $2.054(5)$ & N3-Ru1-N6 & $98.7(2)$ \\
Torsion angles & & N5-Ru1-N4 & $79.23(19)$ \\
N1-C4-C5-N3 & 0.24 & N6-Ru1-N7 & $79.09(19)$ \\
N2-C4-C5-S1 & 1.29 & & \\
\hline
\end{tabular}

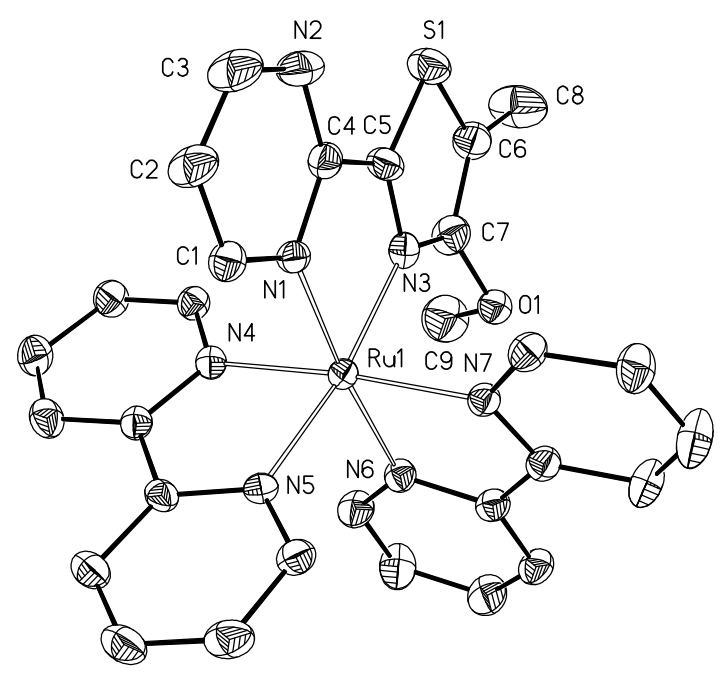

Figure 4. ORTEP drawing of Ru2 showing the labeling scheme of selected atoms. Solvent molecules, hydrogen atoms and the anions $\mathrm{PF}_{6}^{-}$are omitted for the sake of clarity. Ellipsoids are at a probability level of $30 \%$.

\section{Conclusions}

The presented results, which include the first time X-ray structure of a $\mathrm{Ru}(\mathrm{II})$ complex with a 4-hydroxythiazole derivative as a ligand, are promising in terms of the spectroscopic properties of the compounds. The versatile hydroxy group of the ligands allows the connection of the complexes with biological systems via an ester linkage, for example [8]. Together with the easily tunable room temperature emission they can be used as possible sensor molecules. This will be the subject of further research. Also, the application as possible catalysts for $\mathrm{CO}_{2}$ reduction, with the sulfur as the reactive site (as reported already) will be investigated.

\section{Experimental Section}

${ }^{1} \mathrm{H}-,{ }^{13} \mathrm{C}-\mathrm{NMR}$ and the corresponding correlation spectra were recorded on a Bruker $A C-250(250 \mathrm{MHz})$ and a Bruker $A C-400$ (400 MHz) spectrometer. Chemical shifts $(\delta)$ are 
given relative to solvents and all coupling constants are given in Hz. Fluorescence spectra were measured on a Jasco FP 6500. UV/Vis data were collected on a Lambda 19 from PERKIN-ELMER. Elemental analysis was carried out on a Leco CHNS-932. Mass spectra were measured either on a Finnigan MAT SSQ 710 (EI) or MAZ 95 XL (FAB) system.

The quantum yield measurements were carried out on a Hamamatsu C9920-02 QY system. The home-made system consists of an integrated sphere which allows the measurement of absolute quantum yields of dilute solutions of the corresponding compounds. The emission lifetimes were obtained by time-correlated single photon counting (TCSPC) after excitation with a frequency-doubled Tisapphire laser (Tsunami, Newport Spectra-Physics GmbH) as the light source. Repetition rate was reduced to $0.4 \mathrm{MHz}$ by a pulse selector (Model 3980, Newport Spectra-Physics $\mathrm{GmbH})$. The laser beam was frequency doubled in a second harmonic generator (Newport Spectra-Physics $\mathrm{GmbH}$ ) to create the $435 \mathrm{~nm}$ excitation beam. The emission was detected using a $P M C$-100-4 photon-counting module from Becker \& Hickel. A biexponential (to include the response function) fitting function was used to determine luminescence lifetimes.

The intensity data for X-ray structure analysis was collected on a Nonius KappaCCD diffractometer, using graphite-monochromated $\mathrm{Mo}_{\alpha} \mathrm{K}_{\alpha}$ radiation. Data were corrected for Lorentz and polarization effects, but not for absorption effects [16], [17]. The structure was solved by direct methods (SHELXS [18] ) and refined by full-matrix least-squares techniques against Fo $^{2}$ (SHELXL-97 [18]). All hydrogen atoms were included at calculated positions with fixed thermal parameters. All non hydrogen atoms were refined anisotropically [18]. XP (SIEMENS Analytical Xray Instruments, Inc.) was used for structure representations.

Starting materials were commercially obtained from Aldrich and used as received. TLC was from Merck (Polygram SIL G/UV 254 , aluminum oxide $60 \mathrm{~F}_{254}$ ). The material for Column chromatography was also obtained from Merck (Silica gel 60 or Merck aluminum oxide 90 active or neutral; activity stage 1 till 15 with $15 \mathrm{~m} \%$ water).

4-Methoxy-5-methyl-2-pyridine-2-yl-1,3-thiazole (1): A mixture of $1.43 \mathrm{~g}$ (7.45 mmol) of 5-methyl-2-pyridine-2-yl1,3-thiazole-4-ol and $0.48 \mathrm{~g}(8.63 \mathrm{mmol}) \mathrm{K}_{2} \mathrm{CO}_{3}$ were dissolved in $15 \mathrm{~mL}$ of DMSO and stirred for $20 \mathrm{~min}$ at RT. The colour of the solution turned deep red and $1.18 \mathrm{~g} \mathrm{(8.32}$ mmol) methyl iodide was added. After the reaction was finished (TLC), water was added and a yellow precipitate was formed. The mixture was filtered, the residue was washed with water and dried in vacuo. Purification by column chromatography (silica, EtOAc/heptane 1:1) yielded $1.3 \mathrm{~g}$ of the product as a pale yellow solid (yield: $85 \%$ ). ${ }^{1} \mathrm{H}$ NMR (250 MHz, $\left.\mathrm{CDCl}_{3}\right): \delta=2.32(\mathrm{~s}, 3 \mathrm{H}), 4.05(\mathrm{~s}, 3 \mathrm{H})$, $7.24\left(\right.$ ddd, $\left.\mathrm{J}_{1}=7.6, \mathrm{~J}_{2}=4.9, \mathrm{~J}_{3}=1.0,1 \mathrm{H}\right), 7.73\left(\mathrm{ddd}, \mathrm{J}_{1}=7.8\right.$, $\left.\mathrm{J}_{2}=7.8, \mathrm{~J}_{3}=1.7,1 \mathrm{H}\right), 8.06\left(\mathrm{dd}, \mathrm{J}_{1}=8.0, \mathrm{~J}_{2}=1.0,1 \mathrm{H}\right), 8.54$ $\left(\mathrm{dd}, \mathrm{J}_{1}=4.8, \mathrm{~J}_{2}=1.6,1 \mathrm{H}\right) ;{ }^{13} \mathrm{C}-\mathrm{NMR}\left(250 \mathrm{MHz}, \mathrm{CDCl}_{3}\right): \delta$ $=9.5,57.7,109.6,118.7,123.7,136.8,149.3,151.6,159.5$, 160.7; MS (EI): $\mathrm{m} / \mathrm{z}(\%)=206$ (70), $105(100) ; \mathrm{EA}$ $\mathrm{C}_{10} \mathrm{H}_{10} \mathrm{~N}_{2} \mathrm{OS}(206,26 \mathrm{~g} / \mathrm{mol}): \mathrm{C} 58.23$ (calc. 58.29), H 4.89 (5.03), N 13.58 (13.41), S 15.55 (15.63)\%; UV/Vis $\left(\mathrm{CH}_{2} \mathrm{Cl}_{2}\right): \lambda_{\max }(\log \varepsilon)=242 \mathrm{~nm}$ (3.88), $344 \mathrm{~nm}$ (4.12); m.p.: $45.1{ }^{\circ} \mathrm{C}$.

4-Methoxy-5-methyl-2-pyrimidine-2-yl-1,3-thiazole (2): A mixture of $0.16 \mathrm{~g}(0.77 \mathrm{mmol}) 5$-methyl-2-pyrimidine-2-yl1,3-thiazole-4-ol and $134 \mathrm{mg}(0.97 \mathrm{mmol}) \mathrm{K}_{2} \mathrm{CO}_{3}$ were suspended in $10 \mathrm{~mL}$ of DMF. After $30 \mathrm{~min}$, the colour of the solution turned deep red and $109 \mathrm{mg}(0.77 \mathrm{mmol})$ methyl iodide dissolved in $5 \mathrm{~mL}$ of DMF was added over a period of $30 \mathrm{~min}$. The mixture was stirred for $24 \mathrm{~h}$. After removal of the solvent in vacuo, the crude product was purified by column chromatography ( silica, $\mathrm{CH}_{2} \mathrm{Cl}_{2}$ ) yielding $90 \mathrm{mg}$ of a brown solid. Recrystallization from an $\mathrm{MeOH} / \mathrm{H}_{2} \mathrm{O}$ (50:50, $\mathrm{v} / \mathrm{v}$ ) mixture afforded the product as light tan needles (yield: $55 \%) .{ }^{1} \mathrm{H}-\mathrm{NMR}\left(250 \mathrm{MHz}, \mathrm{CDCl}_{3}\right): \delta=2.34$ (s, 3H), 4.12 $(\mathrm{s}, 3 \mathrm{H}), 7.20(\mathrm{t}, \mathrm{J}=4.9,1 \mathrm{H}), 8.77(\mathrm{~d}, \mathrm{~J}=4.9,2 \mathrm{H}) ;{ }^{13} \mathrm{C}-\mathrm{NMR}$ $\left(250 \mathrm{MHz}, \mathrm{CDCl}_{3}\right): \delta=9.53,58.0,112.5,119.9,157.0$, 157.6, 159.6, 161.9; MS (EI): $\mathrm{m} / \mathrm{z}(\%)=207$ (70), 105 (100); $\mathrm{EA} \mathrm{C}_{9} \mathrm{H}_{9} \mathrm{~N}_{3} \mathrm{OS}(207,25 \mathrm{~g} / \mathrm{mol}) \mathrm{C} 52.16$ (calc. 52.33), $\mathrm{H} 4.38$ (4.53), N 20.27 (20.11), S 15.44 (15.44)\%, UV/Vis $\left(\mathrm{CH}_{2} \mathrm{Cl}_{2}\right): \lambda_{\max }(\log \varepsilon)=236 \mathrm{~nm}(3.87), 352 \mathrm{~nm}$ (4.05); m.p.: $61{ }^{\circ} \mathrm{C}$.

General procedure for the formation of thioamides: The nitrile $(0.1 \mathrm{~mol})$ was dissolved in $200 \mathrm{~mL}$ of ethanol and triethylamine $(0.05 \mathrm{~mol})$ was added. Then hydrogen sulfide was passed through the solution until no more gas was consumed. After 1 hour the mixture was filtered and the crude material was recrystallized from EtOH. The compound 2-pyridinethioamide was identical with a sample obtained from Aldrich (m.p.: $138^{\circ} \mathrm{C}$ (lit: $\left.137^{\circ} \mathrm{C}, \mathrm{EtOH}\right)$ ).

5-Phenyl-2-(pyridin-2-yl)-1,3-thiazol-4-ol: A mixture of $13.9 \mathrm{~g}(0.1 \mathrm{~mol})$ 2-pyrimidinethioamide, $24.3 \mathrm{~g}(0.1 \mathrm{~mol})$ ethyl 2-bromphenylacetate and $2.4 \mathrm{~g}(30 \mathrm{mmol})$ pyridine was stirred under an argon atmosphere at $100-110^{\circ} \mathrm{C}$. After the mixture has solidified, ethanol was added $(20 \mathrm{~mL})$ and the stirring was continued at room temperature for $30 \mathrm{~min}$. After filtration, the crude product was recrystallized from EtOH yielding $18.3 \mathrm{~g}$ of the 4-hydroxythiazole as a yellow crystalline compound (yield: $72 \%) .{ }^{1} \mathrm{H}-\mathrm{NMR}(250 \mathrm{MHz}$, DMSO-d6): $\delta=7.25$ (d, J = 7.3, 2H), $7.48(\mathrm{~m}, 3 \mathrm{H}), 7.77$ (d, $\mathrm{J}=7.3,2 \mathrm{H}), 8.00(\mathrm{~m}, 2 \mathrm{H}), 8.61(\mathrm{~d}, \mathrm{~J}=1.3,1 \mathrm{H}), 11.60(\mathrm{~s}$, $1 \mathrm{H}) ;{ }^{13} \mathrm{C}-\mathrm{NMR}(250 \mathrm{MHz}$, DMSO-d6): $\delta=110.8,116.8$, 125.4, 126.6, 126.8, 129.3, 132.3, 138.2, 150.2, 150.6, 159.1, 160.9; EA $\mathrm{C}_{14} \mathrm{H}_{10} \mathrm{~N}_{2} \mathrm{OS}$ (254.31 g/mol): C 66.12 (calc. 66.10), H 3.96 (4.13), N 11.02 (10.95), S 12.61 (12.75)\%; m.p.: $236.3{ }^{\circ} \mathrm{C}$.

\section{4-Methoxy-5-phenyl-2-pyridine-2-yl-1,3-thiazole}

(3): $2.54 \mathrm{~g}(10 \mathrm{mmol})$ of the 5-phenyl-2-(pyridin-2-yl)-1,3thiazol-4-ol was dissolved in $50 \mathrm{~mL}$ of DMSO and the mixture was stirred for $30 \mathrm{~min} .3 .54 \mathrm{~g}(90 \mathrm{mmol}) \mathrm{NaOH}$ dissolved in $20 \mathrm{~mL}$ of $\mathrm{H}_{2} \mathrm{O}$ were added and the solution was stirred again for $5 \mathrm{~min} .1 .7 \mathrm{~g}(12 \mathrm{mmol})$ methyl iodide was then added to the red solution. After the reaction was finished (TLC), water was added until a precipitate appeared. The mixture was filtered and the crude product was recrystallized from EtOH/ $\mathrm{CHCl}_{3}$ yielding $1.9 \mathrm{~g}$ of a yellow compound (Yield: $71 \%) .{ }^{1} \mathrm{H}-\mathrm{NMR}\left(400 \mathrm{MHz}, \mathrm{CDCl}_{3}\right): \delta=$ $4.2(\mathrm{~s}, 3 \mathrm{H}), 7.23-7.32(\mathrm{~m}, 2 \mathrm{H}), 7.38-7.43(\mathrm{~m}, 2 \mathrm{H}), 7.76-$ $7.82(\mathrm{~m}, 3 \mathrm{H}), 8.14\left(\mathrm{dd}, \mathrm{J}_{1}=8.0, \mathrm{~J}_{2}=1.0,1 \mathrm{H}\right), 8.61\left(\mathrm{dd}, \mathrm{J}_{1}=\right.$ $\left.4.9, \mathrm{~J}_{2}=1.7,1 \mathrm{H}\right) ;{ }^{13} \mathrm{C}-\mathrm{NMR}\left(400 \mathrm{MHz}, \mathrm{CDCl}_{3}\right): \delta=57.6$, 114.4, 118.9, 124.0, 126.7, 126.9, 128.7, 131.6, 136.9, 149.3, 151.2, 159.7, 160.2; MS (EI): $\mathrm{m} / \mathrm{z}(\%)=268(60 \%), 121$ $(100 \%)$; $\mathrm{EA} \mathrm{C}_{15} \mathrm{H}_{12} \mathrm{~N}_{2} \mathrm{OS}(268.33 \mathrm{~g} / \mathrm{mol})$ : $\mathrm{C} 67.14$ (calc. 67.01), H 4.51 (4.49), N 10.44 (10.39), S 11.95 (11.81); UV/Vis $\left(\mathrm{CH}_{2} \mathrm{Cl}_{2}\right): \lambda_{\max }(\log \varepsilon)=246 \mathrm{~nm}(3.96), 273 \mathrm{~nm}$ (3.92), 376 [4.32]; m.p.: $213{ }^{\circ} \mathrm{C}$ decomp. 
General procedure for the synthesis of the complexes; example for $\left[R u(b p y)_{2}(1)\right]\left(P F_{6}\right)_{2}(\boldsymbol{R u} 1)$ :

The activated precursor cis-Ru(bpy $)_{2}$ (acetone $)_{2} \mathrm{PF}_{6}$ was synthesized by stirring $180 \mathrm{mg}(0.37 \mathrm{mmol})$ of cis(bpy) $)_{2} \mathrm{RuCl}_{2}$ and $187 \mathrm{mg}(0.74 \mathrm{mmol}) \mathrm{AgPF}_{6}$ in $10 \mathrm{~mL}$ of degassed and dried acetone for $6 \mathrm{~h}$ at RT under an argon atmosphere. The suspension was filtered inert to remove the developed $\mathrm{AgCl} .76 \mathrm{mg}(0.37 \mathrm{mmol})$ of 1 dissolved in $5 \mathrm{~mL}$ of acetone were added to the solution and the mixture was refluxed for $24 \mathrm{~h}$. Subsequently, the reaction mixture was allowed to cool down to RT and the solvent was removed in vасио. The crude product was purified by gel filtration $\left(\mathrm{Al}_{2} \mathrm{O}_{3}\right.$, basic, 15, acetone/toluene 1:1) to remove additionally developed $\mathrm{AgCl}$ and traces of the ligand. After evaporation of the solvents, the solid was dissolved in a small amount of $\mathrm{CH}_{2} \mathrm{Cl}_{2}$ and precipitated with diethyl ether to yield $169 \mathrm{mg}$ of the complex as a bright orange powder (yield: $50 \%$ ). ${ }^{\mathrm{T}} \mathrm{H}-\mathrm{NMR}\left(400 \mathrm{MHz}, \mathrm{CD}_{3} \mathrm{CN}\right): \delta=2.42$ (s, $3 \mathrm{H}), 3.18(\mathrm{~s}, 3 \mathrm{H}), 7.3-7.4(\mathrm{~m}, 2 \mathrm{H}), 7.4\left(\mathrm{ddd}, \mathrm{J}_{1}=7.2, \mathrm{~J}_{2}=\right.$ $\left.5.7, \mathrm{~J}_{3}=1.1,1 \mathrm{H}\right), 7.45\left(\mathrm{ddd}, \mathrm{J}_{1}=7.2, \mathrm{~J}_{2}=5.7, \mathrm{~J}_{3}=1.1,1 \mathrm{H}\right.$ ), $7.55\left(\mathrm{ddd}, \mathrm{J}_{1}=7.2, \mathrm{~J}_{2} 5.7, \mathrm{~J}_{3}=1.1,1 \mathrm{H}\right), 7.61(\mathrm{~d}, \mathrm{~J}=5.5,1 \mathrm{H})$, $7.67(\mathrm{~d}, \mathrm{~J}=5.4,1 \mathrm{H}), 7.76\left(\mathrm{t}, \mathrm{J}_{1}=5.2,2 \mathrm{H}\right), 7.9-8.01(\mathrm{~m}$, $3 \mathrm{H}), 8.02-8.11(\mathrm{~m}, 3 \mathrm{H}), 8.18(\mathrm{~d}, \mathrm{~J}=8.0,1 \mathrm{H}), 8.4-8.6(\mathrm{~m}$, $4 \mathrm{H}) ;{ }^{13} \mathrm{C}-\mathrm{NMR}\left(400 \mathrm{MHz}, \mathrm{CD}_{3} \mathrm{CN}\right): \delta=10.4,61.6,120.2$, $123.2,123.4,123.8,124.28,124.32,126.7,127.0,127.6$, $127.7,127.8,137.4,137.8,137.81,138.0,151.8,152.06$, $152.1,152.5,153.5,157.0,157.1,157.46,157.51,162.1$; MS (FAB): $m / z$ (fragment $)=765\left(\mathrm{Ru}(\text { bpy })_{2} \mathrm{~L} \times \mathrm{PF}_{6}{ }^{-}\right), 620$ (Ru(bpy) $)_{2} \mathrm{~L}$ ); $\mathrm{EA} \mathrm{C}_{30} \mathrm{H}_{26} \mathrm{~F}_{12} \mathrm{~N}_{6} \mathrm{OP}_{2} \mathrm{RuS}$ (909.63): C 39.61 (calc. 39.82), H 2.88 (2.93), N 9.24 (9.08), S 3.53 (3.47)\%; UV/Vis $\left(\mathrm{CH}_{2} \mathrm{Cl}_{2}\right): \lambda_{\max }(\log \varepsilon)=244 \mathrm{~nm}(4.31), 288 \mathrm{~nm}$ (4.80), $321 \mathrm{~nm}$ (4.26), $352 \mathrm{~nm}$ (4.19), $457 \mathrm{~nm}$ (4.12); IR (ATR): $\tilde{v}=3095(\mathrm{w}), 2987(\mathrm{w}), 1605(\mathrm{~m}), 1547(\mathrm{~m}), 1474$ (m), $1447(\mathrm{~m}), 1316(\mathrm{~m}), 1267(\mathrm{w}), 1242(\mathrm{w}), 1162(\mathrm{~m})$, 1139 (w), 1034 (w), 1003 (m), 880 (m), 833 (vs), 760 (s), 730 (s) $\mathrm{cm}^{-1}$; m.p.: $290{ }^{\circ} \mathrm{C}$ decomp.

$\left[R u(b p y)_{2}(2)\right]\left(P_{6}\right)_{2}(\boldsymbol{R u} 2):$ This complex was prepared from $140 \mathrm{mg}(0.29 \mathrm{mmol})$ of $c i s$-(bpy) $)_{2} \mathrm{RuCl}_{2}$ with $146 \mathrm{mg}$ $(0.58 \mathrm{mmol}) \mathrm{AgPF}_{6}$ and $60 \mathrm{mg}(0.29 \mathrm{mmol})$ of 2 to afford $140 \mathrm{mg}$ of the product as an orange-red powder (yield: $53 \%) .{ }^{1} \mathrm{H}-\mathrm{NMR}\left(400 \mathrm{MHz}, \mathrm{CD}_{3} \mathrm{CN}\right): \delta=2.44(\mathrm{~s}, 3 \mathrm{H}), 3.19$ (s, 3H), $7.30-7.40(\mathrm{~m}, 3 \mathrm{H}), 7.48\left(\mathrm{ddd}, \mathrm{J}_{1}=1.3, \mathrm{~J}_{2}=5.6, \mathrm{~J}_{3}\right.$ $=7.5,1 \mathrm{H}), 7.54\left(\mathrm{ddd}, \mathrm{J}_{1}=1.3, \mathrm{~J}_{2}=5.7, \mathrm{~J}_{3}=7.5,1 \mathrm{H}\right), 7.66$ $\left(\mathrm{dd}, \mathrm{J}_{1}=1.2, \mathrm{~J}_{2}=5.3,1 \mathrm{H}\right), 7.74\left(\mathrm{dd}, \mathrm{J}_{1}=1.1, \mathrm{~J}_{2}=5.5,1 \mathrm{H}\right)$, $7.86\left(\mathrm{dd}, \mathrm{J}_{1}=5.8, \mathrm{~J}_{2}=2.0,1 \mathrm{H}\right), 7.93\left(\mathrm{dd}, \mathrm{J}_{1}=1.2, \mathrm{~J}_{2}=5.5\right.$, $1 \mathrm{H}), 7.98-8.10(\mathrm{~m}, 3 \mathrm{H}), 8.08-8.14(\mathrm{~m}, 2 \mathrm{H}), 8.46-8.54(\mathrm{~m}$, $4 \mathrm{H}), 8.86\left(\mathrm{dd}, \mathrm{J}_{1}=4.8, \mathrm{~J}_{2}=2.0,1 \mathrm{H}\right) ;{ }^{13} \mathrm{C}-\mathrm{NMR}(400 \mathrm{MHz}$, $\mathrm{CD}_{3} \mathrm{CN}$ ): $\delta=11.58,62.61,118.22,123.06,124.44,124.78$, $124.83,125.33,125.37,127.70,128.58,128.66,128.98$, $138.53,138.99,153.01,153.02,153.48,153.77,156.44$, $157.90,158.28,158.46,158.49,158.59,160.39,163.72$, 163.84; MS (FAB): $\mathrm{m} / \mathrm{z}$ (fragment) $=766\left(\mathrm{Ru}(\mathrm{bpy})_{2} \mathrm{~L} \times\right.$ $\mathrm{PF}_{6}{ }^{-}$); EA $\mathrm{C}_{29} \mathrm{H}_{25} \mathrm{~F}_{12} \mathrm{~N}_{7} \mathrm{OP}_{2} \mathrm{RuS}$ (910.62): C 38.25 (calc. 38.56), H 2.77 (3.08), N 10.77 (10.82), S 3.52 (3.73)\%; UV/Vis $\left(\mathrm{CH}_{2} \mathrm{Cl}_{2}\right): \lambda_{\max }(\log \varepsilon)=245 \mathrm{~nm}(4.40), 289 \mathrm{~nm}$ (4.83), $332 \mathrm{~nm}$ (4.33), $446 \mathrm{n} \mathrm{m} \mathrm{(4.12);} \mathrm{IR} \mathrm{(ATR):} \tilde{v}=$ 3095 (w), 2987 (w), $1605(\mathrm{~m}), 1571(\mathrm{w}), 1543(\mathrm{~m}), 1474(\mathrm{~s})$, $1447(\mathrm{~m}), 1424(\mathrm{~m}), 1335(\mathrm{~m}), 1316(\mathrm{~m}), 1274(\mathrm{w}), 1243$ (w), $1165(\mathrm{w}), 1139(\mathrm{w}), 1049(\mathrm{w}), 1002(\mathrm{w}), 880(\mathrm{~m}), 823$ (vs), 760 (s), 729 (s) $\mathrm{cm}^{-1}$; m.p.: $255^{\circ} \mathrm{C}$ decomp.

Crystal Data for $\mathbf{R u} 2$ [19]: $\left[\mathrm{C}_{29} \mathrm{H}_{25} \mathrm{~N}_{7} \mathrm{ORuS}\right]^{2+} 2\left[\mathrm{PF}_{6}\right]^{-}, 0.5$ $\mathrm{C}_{2} \mathrm{H}_{8} \mathrm{O}_{2}, 0.5 \mathrm{C}_{2} \mathrm{H}_{3} \mathrm{~N}, \mathrm{Mr}=963.20 \mathrm{gmol}^{-1}$, red-brown prism, size $0.05 \times 0.05 \times 0.05 \mathrm{~mm}^{3}$, monoclinic, space group $P 2_{1} / \mathrm{c}$, $a=12.4229(3), b=25.9841(5), c=13.5263(3) \AA, \beta=$ $117.081(2)^{\circ}, V=3887.56(15) \AA^{3}, T=-90{ }^{\circ} \mathrm{C}, Z=4, \rho_{\text {calcd. }}=$ $1.646 \mathrm{gcm}^{-3}, \mu_{\mathrm{Mo}-\mathrm{K} \alpha}=6.38 \mathrm{~cm}^{-1}, F(000)=1932,27450$ reflections in $h(-14 / 16), k(-33 / 33), l(-17 / 17)$, measured in the range $2.90^{\circ} \leq \Theta \leq 27.49^{\circ}$, completeness $\Theta_{\max }=99 \%$, 8835 independent reflections, $R_{\text {int }}=0.0535,5982$ reflections with $F_{\mathrm{o}}>4 \sigma\left(F_{\mathrm{o}}\right), 496$ parameters, 0 restraints, $R 1_{\mathrm{obs}}=$ $0.0773, w R_{\text {obs }}^{2}=0.2025, R 1_{\text {all }}=0.1168, w R_{\text {all }}^{2}=0.2262$, $\mathrm{GOOF}=1.050$, largest difference peak and hole: $1.341 /$ $0.754 \mathrm{e} \AA^{-3}$.

$\left[\mathrm{Ru}(\mathrm{bpy})_{2}(3)\right]\left(\mathrm{PF}_{6}\right)_{2}(\boldsymbol{R u} 3)$ : This complex was prepared from $140 \mathrm{mg}(0.29 \mathrm{mmol})$ of $c i s-(\mathrm{bpy})_{2} \mathrm{RuCl}_{2}$ with $146 \mathrm{mg}$ $(0.58 \mathrm{mmol}) \mathrm{AgPF}_{6}$ and $75 \mathrm{mg}(0.28 \mathrm{mmol})$ of 3 to afford $138 \mathrm{mg}$ of the product as an orange powder (yield: $68 \%$ ). ${ }^{1} \mathrm{H}-\mathrm{NMR}\left(400 \mathrm{MHz}, \mathrm{CD}_{3} \mathrm{CN}\right): \delta=2.96(\mathrm{~s}, 3 \mathrm{H}), 7.32-7.42$ $(\mathrm{m}, 3 \mathrm{H}), 7.44-7.59(\mathrm{~m}, 7 \mathrm{H}), 7.67\left(\mathrm{t}, \mathrm{J}_{1}=4.8,2 \mathrm{H}\right), 7.80(\mathrm{dd}$, $\left.\mathrm{J}_{1}=9.3, \mathrm{~J}_{2}=5.4,2 \mathrm{H}\right), 7.95-8.15(\mathrm{~m}, 6 \mathrm{H}), 8.26(\mathrm{~d}, \mathrm{~J}=8.0$, $1 \mathrm{H}) ;{ }^{13} \mathrm{C}-\mathrm{NMR}\left(400 \mathrm{MHz}, \mathrm{CD}_{3} \mathrm{CN}\right): \delta=62.4,124.42$, $124.47,124.68,124.91,125.35,125.39,127.7,128.45$, $128.70,128.74,128.89,128.98,129.22,130.43,130.89$, $138.45,138.89,138.92,139.11,152.84,153.07,153.13$, $153.25,153.74,154.34,158.05,158.49,158.56,159.37$, 162.0; MS (FAB): $m / z$ (fragment) $=827\left(\mathrm{Ru}(\mathrm{bpy})_{2} \mathrm{~L} \mathrm{PF}_{6}{ }^{-}\right)$, $682\left(\mathrm{Ru}(\mathrm{bpy})_{2} \mathrm{~L}\right)$; MS (micro-ESI): exact molecular mass $\mathrm{C}_{35} \mathrm{H}_{28} \mathrm{~N}_{6} \mathrm{OSRuPF}_{6}$ for ${ }^{96} \mathrm{Ru}=821.0763$, found 821.0764; EA C ${ }_{35} \mathrm{H}_{28} \mathrm{~F}_{12} \mathrm{~N}_{6} \mathrm{OP}{ }_{2} \mathrm{RuS}$ (971.70): C 43.26 (calc. 42.82), $\mathrm{H}$ 2.90 (3.39), N 8.65 (8.38), S 3.30 (2.97)\%; UV/Vis $\left(\mathrm{CH}_{2} \mathrm{Cl}_{2}\right): \lambda_{\max }(\log \varepsilon)=246 \mathrm{~nm}$ (4.43), $289 \mathrm{~nm}$ (4.83), 368 $\mathrm{nm}$ (4.32), $457 \mathrm{~nm}$ (4.12); IR (ATR): $\tilde{v}=3095$ (w), 3025 $(\mathrm{w}), 1628(\mathrm{w}), 1620(\mathrm{~m}), 1574(\mathrm{w}), 1540(\mathrm{~m}), 1470(\mathrm{~m})$, $1447(\mathrm{~m}), 1428(\mathrm{w}), 1402(\mathrm{w}), 1332(\mathrm{w}), 1316(\mathrm{~m}), 1267$ $(\mathrm{w}), 1242(\mathrm{w}), 1162(\mathrm{~m}), 1127(\mathrm{w}), 1070(\mathrm{w}), 1030(\mathrm{w})$, $1003(\mathrm{~m}), 972(\mathrm{w}), 945(\mathrm{w}), 880(\mathrm{~m}), 830(\mathrm{vs}), 764(\mathrm{~s}), 730$ (s), 700 (s) $\mathrm{cm}^{-1}$; m.p.: $190^{\circ} \mathrm{C}, \mathrm{CH}_{3} \mathrm{CN} /$ diethylether.

\section{Acknowledgments}

We gratefully acknowledge the Deutsche Forschungs Gemeinschaft for financial support. We thank DC C. Friebe (IOMC), Jena, and DC R. Siebert (IPHT), Jena, for the measurements of the quantum yields and emission lifetimes, respectively.

[1] S. Campagna, F. Puntoriero, F. Nastasi, G. Bergamini, V. Balzani, Top. Curr. Chem., 2007, 280, 117-214; b) V. Balzani, G. Bergamini, S. Campagna, F. Puntoriero, Top. Curr. Chem., 2007, 280, 1-36; c) L. Flamigni, A. Barbieri, C. Sabatini, B. Ventura, F. Barigeletti, Top. Curr. Chem., 2007, 281, 143203; d) V. Balzani, A. Juris, Coord. Chem. Rev., 2001, 211, 97-115; e) V. Balzani, A. Juris, M. Venturi, Chem. Rev., 1996, 96, 759-833; f) A. Juris, V. Balzani, F. Barigelletti, S. Campagna, P. Belser, A. von Zelewsky, Coord. Chem. Rev., 1988, 84, 85-277.

[2] G. J. Meyer, Inorg. Chem., 2005, 44, 6852-6864; b) A. Hagefeld, M. Grätzel, Acc. Chem. Res., 2000, 33, 269; c) M. Grätzel, Inorg. Chem., 2005, 44, 6841-6851.

[3] R. P. S. Chaplin, A. A. Wragg, J. Appl. Electrochem., 2003, 33, 1107; b) K. Tanaka, D. Ooyama, Coord. Chem. Rev., 2002, 226,211 .

[4] A. Begum, P. G. Pickup, Electrochem. Commun., 2007, 9, 2525-2528. 
[5] B. J. MacLean, P. G. Pickup, J. Mater. Chem. 2001, 11, 13571363; b) G. Orellana, A. M. Braun, J. Photochemistry and Photobiology A: Chemistry, 1989, 48, 277-289

[6] U.-W. Grummt, D. Weiß, E. Birckner, R. Beckert, J. Phys. Chem. A., 2007, 111, 1104-1110.

[7] C. D. Geddes, J. R. Lakowitz in Reviews in Fluorescence, Kluwer Academics/Plenum Publishers, New York, 2004, vol.1, pp. 137-149.

[8] D. Weiss, S. Trupp, L. F. M. L. Ciscato, R. Beckert, E. Anders, Journal of Sulfur Chemistry, 2009, 30, 109-118.

[9] B. P. Sullivan, D. J. Salmon, T. J. Meyer, Inorg. Chem., 1978, 17,3334 .

[10] D. N. Leea, J. K. Kima, H. S. Parka, Y. M. Juna, R. Y. Hwangb, W.-Y. Leeb, B. H. Kim, Synthetic Metals, 2005, 150, 93-100.

[11] J. Popp, M. Reichenbaecher in Strukturanalytik organischer und anorganischer Verbindungen, B. G. Teubner Verlag, Wiesbaden, 2007, vol.1, p. 136.

[12] W. Zhang, J.-H. Liu, J.-X. Pan, P. Li, L.-C. Sun, Polyhedron, 2008, 27, 1173

[13] D. P. Rillema, T. G. Taghdiri, D. S. Jones, C. D. Keller, L. A. Worl, T. J. Meyer, H. A. Levy, Inorg. Chem., 1987, 26, 578.

[14] B. Mehmetaj, J. G. Haasnoot, L. De Cola, G. A. van Albada, T. Mutikainen, U. Turpeinen, J. Reedijk, Eur. J. Inorg. Chem., 2002, 7, 1765-1771.

[15] S. Stagni, E. Orselli, A. Palazzi, L. De Cola, S. Zacchini, C. Femoni, M. Marcaccio, F. Paolucci, S. Zanarini, Inorg. Chem., 2007, 46, 9126-9138.

[16] COLLECT, Data Collection Software; Nonius B.V., Netherlands, 1998.

[17] Z. Otwinowski \& W. Minor, „Processing of X-Ray Diffraction Data Collected in Oscillation Mode", in Methods in Enzymology, Macromolecular Crystallography, Part A, edited by C.W. Carter \& R.M. Sweet, Academic Press, San Diego, 1997, vol. 276, pp. 307-326.

[18] a) G. M. Sheldrick, Acta Crystallogr. Sect. A, 1990, 46, 467473; b) G. M. Sheldrick "SHELX-97", University of Göttingen, Germany, 1997.

[19] CCDC-753509 (Ru2) and CCDC-752318 (5) contains the supplementary crystallographic data for this paper. These data can be obtained free of charge via www.ccdc.cam.ac.uk/conts/retrieving.html (or from the Cambridge Crystallographic Data Centre, 12, Union Road, Cambridge CB2 1EZ, UK; fax: (+44) 1223-336-033; or deposit@ccdc.cam.ac.uk).

Received: ((will be filled in by the editorial staff)) Published online: ((will be filled in by the editorial staff) 


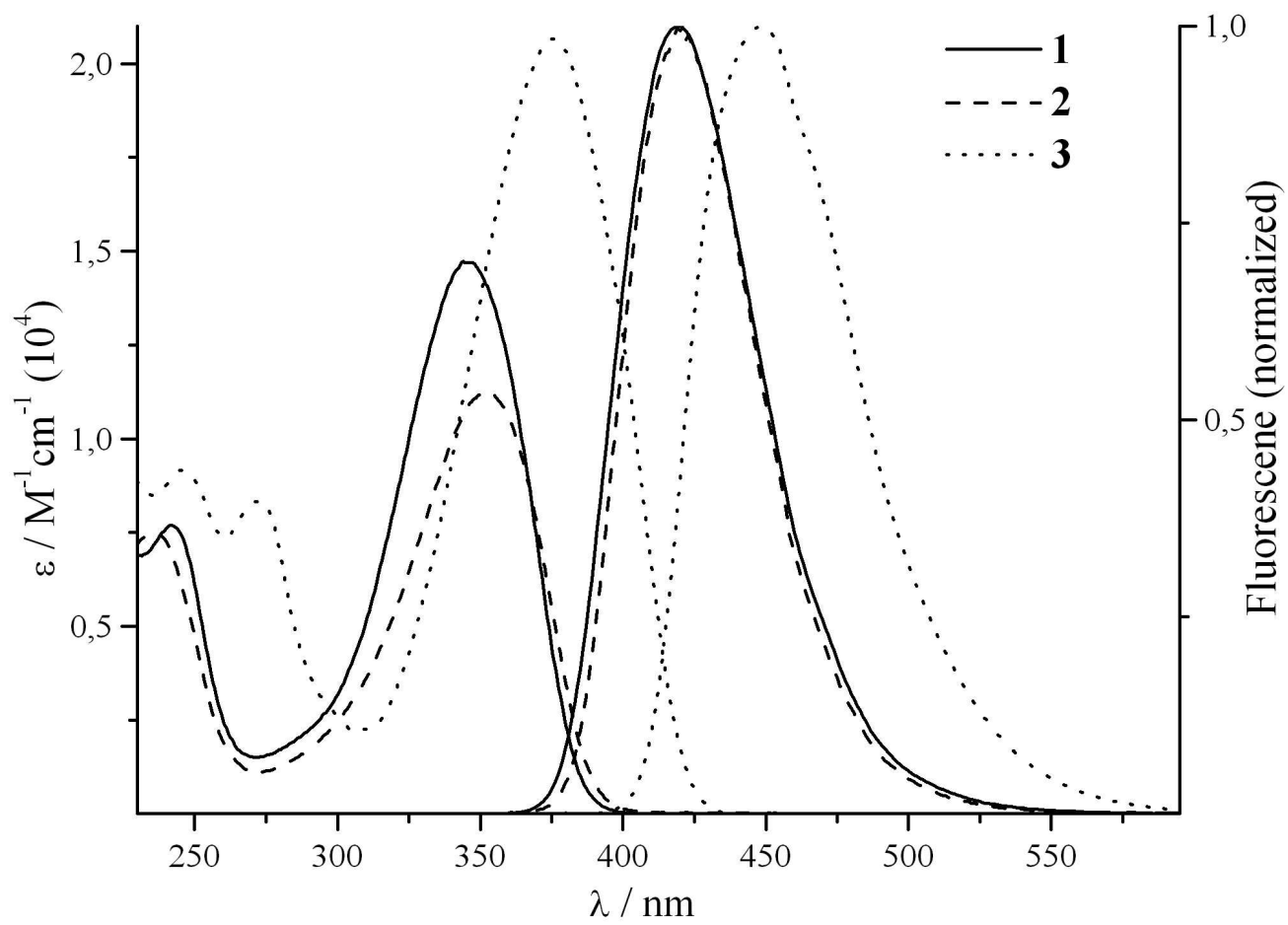

UV/Vis and fluorescence spectra of the ligands 1 to 3 measured in $\mathrm{CH} 2 \mathrm{Cl} 2$ at room temperature $84 \times 61 \mathrm{~mm}(600 \times 600 \mathrm{DPI})$ 


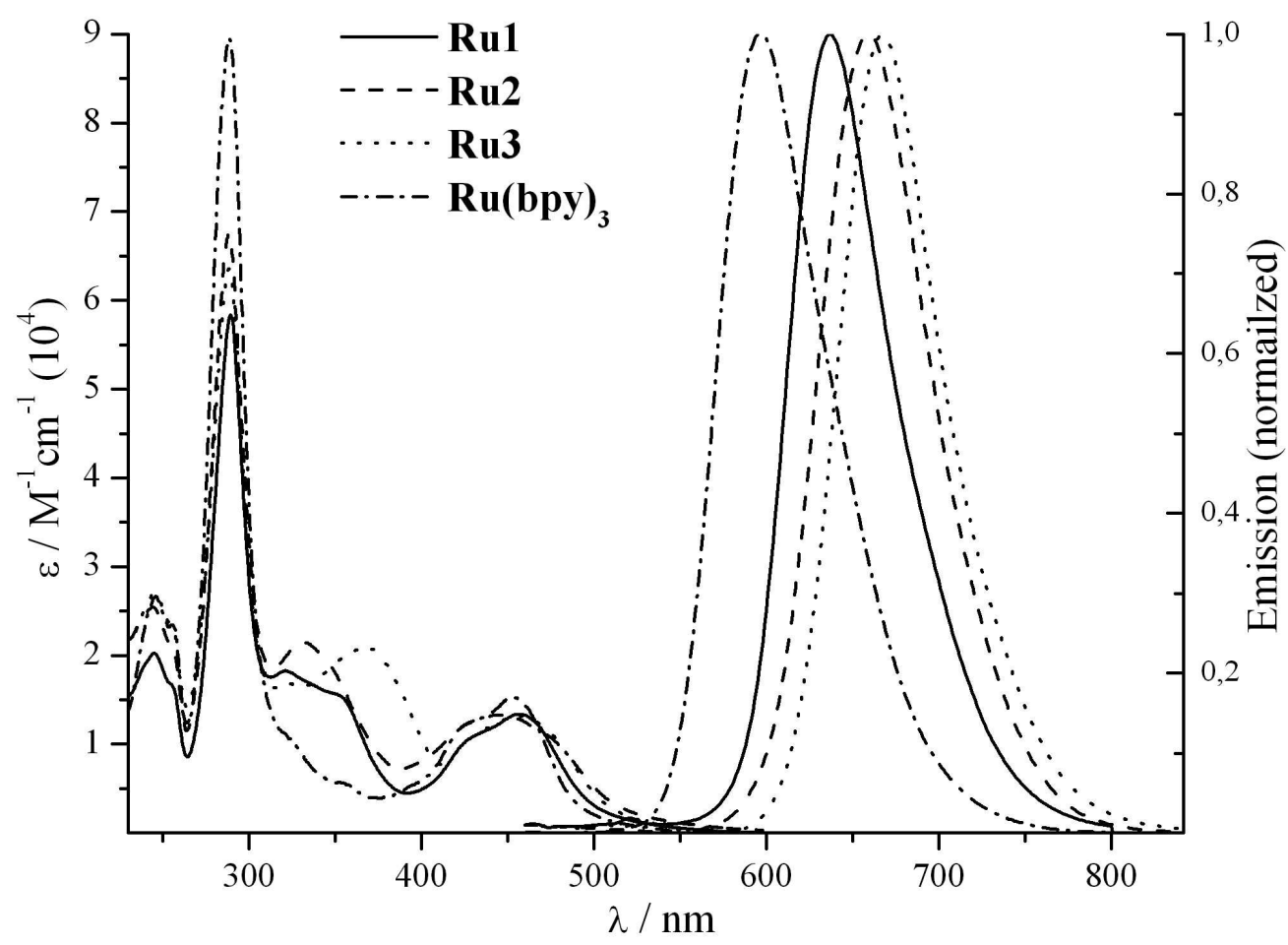

UV/Vis and emission spectra of Ru1 to Ru3 and $\mathrm{Ru}$ (bipy) 3 measured in $\mathrm{CH} 2 \mathrm{Cl} 2$ at room temperature $84 \times 62 \mathrm{~mm}(600 \times 600 \mathrm{DPI})$ 